\title{
Characterization of traditional Algerian cheese "Bouhezza" prepared with raw cow, goat and sheep milks
}

\author{
Sofiane BOUDALIA ${ }^{1,2 *}$ (D), Ali BOUDEBBOUZ ${ }^{1,2}$, Yassine GUEROUI ${ }^{3}$, Aissam BOUSBIA ${ }^{1,2}$, Mhamed BENADA ${ }^{1}$, \\ Choubaila LEKSIR ${ }^{2,3}$, Zeki BOUKAABENE ${ }^{1}$, Aya SAIHI ${ }^{1}$, Hadjer TOUAIMIA ${ }^{1}$, Abderrahmane AÏT-KADDOUR ${ }^{4}$, \\ Mabrouk CHEMMAM ${ }^{1,2}$
}

\begin{abstract}
"Bouhezza" is an Algerian traditional fermented soft-ripened cheese, found and consumed in the Northeast of Algeria. The objective of this study was to explore the preparation process (traditional making diagram) of "Bouhezza" cheese and to study the effect of the type of raw milk (cow, goat and sheep) on the yield and organoleptic characteristics of the fresh "Bouhezza" cheese. "Bouhezza" cheese was handmade in a traditional way using milk of three species (cow, goat and sheep). The milk used has been the subject of physicochemical and bacteriological analysis. Cheese yield for sheep's milk is higher $(\mathrm{p}<0.05)$ than cheese yield for cow's and sheep's milk. For sensory analysis, score registered for cheese of cow's milk $\geq 5$ suggested higher acceptability for this cheese. Here, we exposed the "Bouhezza" cheese, its history, origin and manufacturing processes. From the physicochemical and bacteriological analysis of milk, results show that all criteria analyzed respond almost to the required standard. The sensory qualities of the three types of cheese show that cow cheese was classified as the most satisfactory cheese for the majority of criteria (taste. color and texture). Finally, and for higher yield, results supported the use of sheep milk as a raw material.
\end{abstract}

Keywords: traditional cheese; "Bouhezza"; bacteriological criteria; physicochemical parameters; sensory evaluation.

Practical Application: Algerian "Bouhezza" cheese: his history, origin manufacturing processes and characteristics.

\section{Introduction}

Traditional products are considered as a very important way to keep the regional and national identity of peoples. We meet traditional recipes handed down from generation to generation, challenging time and space. Among these products, traditional cheeses are one of the food product that have become the image of different countries or region of origin, they differ from each other by their making process, ripening time (if applied), type of milk used, texture, color, flavor, coagulation type (enzymatic and/or acid)...etc. Among these traditional cheeses we can cite "Klila" chesses produced in Algeria (Leksir et al., 2019; Leksir \& Chemmam, 2015); "Roquefort", "Cheddar", "Emmental", “Camembert", "Parmesan" and "Picodon" produced in France (Bertozzi \& Panari, 1993; Leclercq-Perlat et al., 2019; Quetier et al., 2005); "Maraj' o" cheese, "Manteiga", "Coalho", "Caipira", "Canastra" and "Minas" cheeses produced in Brazil (Moraes et al., 2018; Sant'Anna et al., 2017; Kamimura et al., 2019); "Quesillo" cheese produced in Argentine (Oliszewski et al., 2007); "Vlasina" cheese produced in Serbia (Terzic-Vidojevic et al., 2013); "Anevato" cheese produced in Greece (Hatzikamari et al., 1999); "Chihuahua" cheese produced in Mexico (Sánchez-Gamboa et al., 2018) and "Babia-Laciana" cheese produced in Spain (Franco et al., 2003).
Unlike other countries, in Algeria traditional cheeses are few in number but not fully enumerated and as little been studied (Dubeuf et al., 2010); about ten types of cheese are known in different regions of the country (Aissaoui Zitoun et al., 2011). Among these cheeses are "klila", "bouhezza", "mechouna" and "madghissa", in the region of Chaouia, "takammérite" and "aoules" in the south, "igounanes" in the region of Kabylie (Aissaoui Zitoun et al., 2011, 2012; Ben Danou, 1929; Benamara et al., 2016; Benkerroum, 2013; Khoualdi, 2017; Leksir \& Chemmam, 2015; Licitra et al., 2019; McSweeney et al., 2017; Medjoudj et al., 2017a, b; Ramalho Ribeiro et al., 2006).

Unfortunately, several of these cheeses are endangered, for various reasons including the unavailability of fodder, rural exodus and changing dietary habits. We do not know the future of these products, but we must do everything possible to know them, maintain their existence and encourage their manufacture. The preparation processes of these cheeses come from earlier generations and have been passed down from generation to generation (Leksir et al., 2019). So, registration of different information about traditional cheeses is part of the preservation of a nation's culinary heritage and culture which must be well characterized and protected. Also, the certification 
of a geographical indication "Protected Designation of Origin PDO) for these artisanal cheeses may encompass an essential milestone for adding value and, an economic resource for farmers (Kamimura et al., 2019).

"Bouhezza" cheese has long been known in the Chaouia region of eastern Algeria. It is made from goat, sheep, cow milk or mixture (Marino et al., 2012; Medjoudj et al., 2017a, b) and considered not only as a food product but also as an integral part of "Chaouias" people life. The manufacture of "Bouhezza" has the particularity of involving coagulation, draining, salting and refining simultaneously. The cheese is obtained after transformation of the "Lben" in a "skinbag" or a "Chekoua" made of goatskin previously treated with salt and juniper (Aissaoui Zitoun et al., 2011). "Chekoua" serves, at first sight, container and media filtering for sewage (Aissaoui Zitoun et al., 2011, 2012; Chaker, 1986). Outsides, these elements, it is scientifically poorly studied. The current study deals with the traditional preparation of "Bouhezza" by the people of "Chaouias" (traditional making diagram) and at the same time explore the effect of the type of raw milk of three species (cow, goat and sheep) on the yield and organoleptic characteristics of the fresh "Bouhezza" cheese.

\section{Materials and methods}

\subsection{Study area and sampling plan}

The samples are collected from four areas located in the in North-East of Algeria (Guelma, Souk Ahras and Tébessa) and in the center of Algeria: (Djelfa) (Figure 1). A total of 27 samples of raw milk of three species (goat, cow, and sheep) were collected and used for cheese making. From each farm, about 1.5-2 L were taken in sterile glass bottles and placed immediately in a cooler, then transported to the laboratory, where they are stored at $4{ }^{\circ} \mathrm{C}$ until analysis and cheese making. All bottles are previously autoclaved at a temperature of $121^{\circ} \mathrm{C}$, under a pressure of 1 bar for 15 minutes.
The vials are filled from a container of mixing milk, respecting the Good Laboratory Practices (GLP), and the rules of asepsis (disinfection of the hands). In order to take account of the real field conditions, no conservative was added. Total volumes of 20-50 mL from each sample were collected for microbiological physicochemical analysis.

\subsection{Raw milk analysis}

\section{Physicochemical and bacteriological analysis}

For physicochemical analysis, $\mathrm{pH}$ was measured using a $\mathrm{pH}$ meter Adwa, AD1000 and acidity was determined according to the method described by Tadjine et al. (2019). Freezing point, conductivity, fat content, protein content, lactose content, mineral content and vitamins of milk were measured with a Lactoscan milk analyzer (Milkotronic LTD Europe) according to the manufacturer's instructions.

For bacteriological analysis, samples preparation and dilutions were performed according to the recommendations of the International Dairy Federation (1991): 1) The Total Mesophilic Aerobic Flora (TMAF) was enumerated using Plate Count Agar (PCA) and incubated at $30^{\circ} \mathrm{C}$ for $72 \mathrm{~h} ; 2$ ) The Total Coliforms and Fecal Coliforms were determined using Violet Red Lactose Bile agar (VRBL) incubated at $37^{\circ} \mathrm{C}$ for total coliforms, and $44^{\circ} \mathrm{C}$ for fecal coliforms; 3 ) Sulphite Reducing Clostridium was determined using enrichment method in a liquid medium; 4) The enumeration of Staphylococci suspected pathogens was conducted using a selective medium (Chapman) and incubated at $37^{\circ} \mathrm{C}$ for 24 to 48 hours. A positive culture of Staphylococci is indicated by the formation of a black precipitate surrounded by a white halo; 5) For Salmonella, two mediums were used to enumerate the colonies: Selenite-Cystine for enrichment at $37^{\circ} \mathrm{C}$ for $12 \mathrm{~h}$, and SS medium (Salmonella-Shigella) for isolation at $37^{\circ} \mathrm{C}$ for $24 \mathrm{~h}$. Salmonella appears like colorless and transparent colonies with or without a black center of small size ( 2 to $4 \mathrm{~mm}$ in diameter).

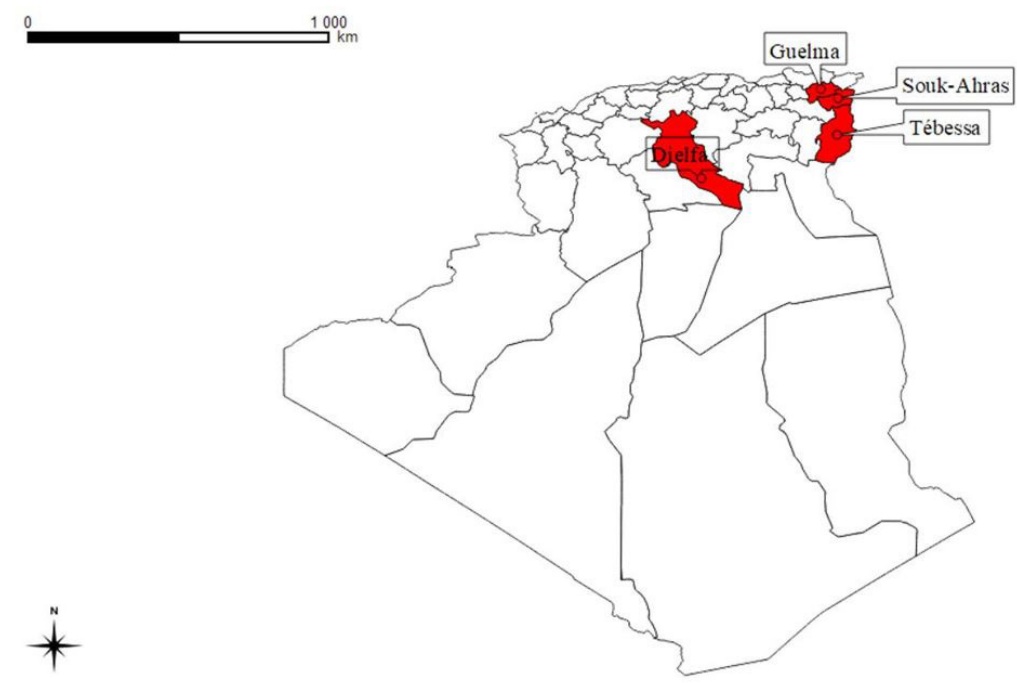

Figure 1. Location map of the study area. Milk samples are collected from four areas located in the North East of Algeria (Guelma, Souk Ahras and Tébessa) and in the center of Algeria: (Djelfa). Raw milk of three species (goat, cow, and sheep) were collected and used for "Bouhezza" cheese making. 


\subsection{Data collection about the traditional preparation of "Bouhezza"}

A household survey focused on group discussion was performed in this study (Ghosh et al., 2014; Leksir et al., 2019). The present documentation of "Bouhezza" preparation is based on the questionnaires and insight observation from farmers. A total of 45 people including producers, sellers, and consumers were involved in the interviews and discussions, after taking their prior consent. The survey was conducted through face-to-face interaction to either heads or knowledgeable adults of households. During the data collection on "Bouhezza", especially while conducting the interviews, observations were made and the comments of responders and other people were noted.

The research protocol for the sensory study and the household survey have been developed and validated by the ethics committee of the University of Guelma-Algeria.

\subsection{Cheese making}

The raw milk is left at room temperature, until its spontaneous coagulation that takes 24 to 72 hours depending on the seasonal temperature. This curdled milk by natural fermentation is called "Rayeb" (or Raï). Then "Rayeb" must be churned for 30 to 40 minutes to make the "Lben" in the the "Chekoua". The addition of lukewarm water to the "Raïb" (about 10\% (v/v)) makes it possible to reduce the temperature to the proper level to collect the grains of butter. After partial extraction of the traditional butter (Zebda Beldia), one obtains a thick liquid, the buttermilk named "Lben".

After thorough conversation and field observation, "Bouhezza" preparation stretches over a period of eight days, and it can be broadly divided into the following steps: salting is done in the "Lben". The added amount is an average of 1 tablespoon/L. The "Chekoua", in which the "Lben" is introduced (a quantity of 3.6 to $3.8 \mathrm{~L}$ ) is suspended in a ventilated place and in the shade. Once the cheese is refined, the raw milk $(100 \mathrm{~mL} / 4 \mathrm{~L})$ is added to adjust the acidity and salinity of the finished product. Cheese was stored in pottery jars/ glass or food containers for a few weeks at a temperature that varies between $4{ }^{\circ} \mathrm{C}$ and $8{ }^{\circ} \mathrm{C}$.

\subsection{Real yields in cheese, dairy whey and butter}

After each series of production, the amount of whey, butter, and cheese is measured in order to calculate the yield using the Equation 1 (Tadjine et al., 2019).

\footnotetext{
Real yield of cheese (butter or whey) $=$ The weight of cheese obtained $(\mathrm{kg}) /$ volume of milk $(L) \times 100($ in $\mathrm{kg} / 100 \mathrm{~L})$
}

\subsection{Sensory analysis}

In order to obtain basic information about the sensory characteristics of "Bouhezza" cheese, a consumer acceptability test was conducted using 9 point unstructured hedonic scale (Boudalia et al., 2016b; Oliveira et al., 2017; Ruvalcaba-Gómez et al., 2020); a randomized panel consisting of 20 students, and teachers-researchers of both sexes from University of 8 Mai 1945 Guelma: 91\% of people are under the age of 30 years old, and $9 \%$ between 30 to 45 years old.
The following five sensory characteristics were selected for evaluation, overall appreciation, taste, texture, smell and color. They were scored from 1 (dislike extremely) to 9 (like extremely). The overall assessment is requested at the beginning of the questionnaire to get as close as possible to the real conditions of purchase and to prevent the consumer from decomposing the sensations. Additional information on the sex, age and frequency of consumption of cheeses is also required to enable the characterization of the sample population interviewed.

Cheese is considered acceptable (from a hedonic point of view) if at least $50 \%$ of our participants give a score greater than or equal to 6 (likes slightly) (Conti-Silva et al., 2011; Volpini-Rapina et al., 2012).

Prior to the start of testing, all participants spread to questions about possible food allergies to cheese components (milk protein). Then, the cheese (40 g), which was freshly prepared, placed in plastic plates, then presented to the panelist for tasting. Participants answered questionnaires (Sęczyk et al., 2016). The questionnaires duly completed by the tasters were removed at the end of the evaluation and the data was organized and processed.

The research protocol for the sensory study and the household survey have been developed and validated by the ethics committee of the University of Guelma-Algeria.

\subsection{Statistical analysis}

The results of the physicochemical analysis, cheese yield, as well as the results of the sensory analysis, are expressed in the form of means \pm SEM (Standard Error Mean). The differences between the different parameters are the subject of an analysis of variance (ANOVA) followed by a comparison of means (Dunnet test or Tukey test) when the conditions of normality and homogeneity of the variances are respected (test Kolmogorov-Smirnov), and possibly a non-parametric analysis of variance (Kruskal-Wallis). For bacteriological analyses, results were expressed by the presence or absence of germs. All the colonies were counted as Colony Forming Units per mL of milk (CFU/mL) (International Dairy Federation, 1991).

For sensory analysis, statistical analysis of the data was analyzed on the basis of a two-factor analysis of variance (ANOVA) "hedonic score vs. cheese, sex", considering "sex" and "cheese" as independent variables. "sex $\times$ cheese" interactions are also reported.

The data was processed using Minitab software (Minitab, Ltb., United Kingdom, Version 16). The minimum threshold of significance retained is $\mathrm{p}<0.05$.

\section{Results and discussion}

\subsection{Physicochemical and bacteriological qualities of raw milk}

Results from physicochemical and bacteriological analyses of raw milk for the three species presented respectively in Tables 1 and 2 satisfy the standard of analyzes criteria (Food and Agriculture Organization of the United Nations, 2002). 
Table 1. Physicochemical qualities of the analyzed samples $(\mathrm{N}=27$ samples).

\begin{tabular}{|c|c|c|c|c|c|c|}
\hline Parameters & Species & Mean & SEM & CV (\%) & Min & Max \\
\hline \multirow[t]{3}{*}{ Fat content (\%) } & Cow & $3.28^{\mathrm{a}}$ & 0.08 & 7.18 & 3.00 & 3.58 \\
\hline & Goat & $3.23^{\mathrm{a}}$ & 0.09 & 8.36 & 2.81 & 3.80 \\
\hline & Sheep & $1.82^{\mathrm{b}}$ & 0.08 & 13.44 & 1.57 & 2.30 \\
\hline \multirow[t]{3}{*}{ Protein content (\%) } & Cow & $3.13^{\mathrm{b}}$ & 0.20 & 18.69 & 2.44 & 4.15 \\
\hline & Goat & $3.05^{\mathrm{b}}$ & 0.32 & 31.48 & 1.98 & 4.74 \\
\hline & Sheep & $4.63^{\mathrm{a}}$ & 0.05 & 2.93 & 4.49 & 4.87 \\
\hline \multirow[t]{3}{*}{ Lactose (\%) } & Cow & $4.70^{\mathrm{a}}$ & 0.29 & 18.65 & 3.67 & 6.23 \\
\hline & Goat & $2.97^{\mathrm{b}}$ & 0.29 & 29.33 & 1.89 & 4.50 \\
\hline & Sheep & $4.30^{\mathrm{a}}$ & 0.07 & 4.63 & 3.90 & 4.62 \\
\hline \multirow[t]{3}{*}{ Minerals and Vitamins (\%) } & Cow & $0.70^{\mathrm{a}}$ & 0.04 & 18.69 & 0.55 & 0.93 \\
\hline & Goat & $0.50^{\mathrm{b}}$ & 0.05 & 28.85 & 0.32 & 0.75 \\
\hline & Sheep & $0.73^{\mathrm{a}}$ & 0.01 & 3.31 & 0.70 & 0.77 \\
\hline \multirow[t]{3}{*}{ Dry Degreased Extract (\%) } & Cow & $8.55^{\mathrm{a}}$ & 0.53 & 18.60 & 6.67 & 11.33 \\
\hline & Goat & $6.61^{\mathrm{b}}$ & 0.65 & 29.28 & 4.21 & 10.01 \\
\hline & Sheep & $9.77^{\mathrm{a}}$ & 0.10 & 3.13 & 9.40 & 10.28 \\
\hline \multirow[t]{3}{*}{ Added Water (\%) } & Cow & $3.62^{\mathrm{b}}$ & 2.11 & 174.46 & 0.00 & 18.44 \\
\hline & Goat & $25.79^{\mathrm{a}}$ & 7.24 & 84.21 & 0.00 & 56.53 \\
\hline & Sheep & $0.00^{\mathrm{b}}$ & 0.00 & 0.00 & 0.00 & 0.00 \\
\hline \multirow[t]{3}{*}{$\mathrm{pH}$} & Cow & $6.48^{\mathrm{a}}$ & 0.06 & 2.93 & 6.00 & 6.63 \\
\hline & Goat & $6.63^{\mathrm{ab}}$ & 0.03 & 1.18 & 6.52 & 6.78 \\
\hline & Sheep & $6.71^{\mathrm{b}}$ & 0.08 & 3.65 & 6.26 & 7.05 \\
\hline \multirow[t]{3}{*}{ Density $\left(\mathrm{mg} \cdot \mathrm{cm}^{-3}\right)$} & Cow & $1031.90^{\mathrm{a}}$ & 2.11 & 0.61 & 1024.90 & 1042.80 \\
\hline & Goat & $1022.7^{\mathrm{b}}$ & 2.48 & 0.73 & 1013.00 & 1035.50 \\
\hline & Sheep & $1033.10^{\mathrm{a}}$ & 1.36 & 0.39 & 1023.20 & 1035.90 \\
\hline \multirow[t]{3}{*}{ Freezing point $\left({ }^{\circ} \mathrm{C}\right)$} & Cow & $-0.55^{\mathrm{b}}$ & 0.04 & -20.57 & -0.75 & -0.42 \\
\hline & Goat & $-0.38^{\mathrm{a}}$ & 0.04 & -33.37 & -0.58 & -0.23 \\
\hline & Sheep & $-0.56^{\mathrm{b}}$ & 0.01 & -4.74 & -0.60 & -0.52 \\
\hline \multirow[t]{3}{*}{ Conductivity $\left(\mu \mathrm{S} . \mathrm{cm}^{-1}\right)$} & Cow & $4.94^{\mathrm{a}}$ & 0.25 & 15.15 & 4.03 & 5.82 \\
\hline & Goat & $4.55^{\mathrm{a}}$ & 0.19 & 12.18 & 3.59 & 5.12 \\
\hline & Sheep & $3.87^{\mathrm{b}}$ & 0.06 & 4.81 & 3.60 & 4.13 \\
\hline
\end{tabular}

SEM: Standard Error Mean; CV: coefficient of variation; Max: maximum; Min: minimum. Means which are denoted by different letters (a, b) indicate significantly different mean values between milk from the here species and for the same parameter (Fat, protein and lactose, minerals and vitamins, Dry Degreased Extract, Added Water, pH, Density, Freezing point and Conductivity).

Table 2. Bacteriological qualities of the analyzed samples ( $\mathrm{N}=27$ samples).

\begin{tabular}{cccc}
\hline Flores $(\mathrm{UFC} / \mathrm{mL})$ & Species & Mean \pm SEM & Standard $(\mathrm{CFU} / \mathrm{mL})$ \\
\hline TMAF $\left(10^{5}\right)$ & Cow & $1.13 \pm 1.26$ & $10^{5}$ \\
& Goat & $0.87 \pm 1.05$ & $10^{5}$ \\
& Sheep & $1.37 \pm 1.66$ & $10^{5}$ \\
F. Col. $\left(10^{3}\right)$ & Cow & $1.03 \pm 1.65$ & $10^{3}$ \\
& Goat & $0.56 \pm 0.84$ & $10^{3}$ \\
& Sheep & $1.12 \pm 1.33$ & $10^{3}$ \\
T. Col. $\left(10^{3}\right)$ & Cow & $1.02 \pm 1.45$ & $10^{3}$ \\
& Goat & $0.96 \pm 1.01$ & $10^{3}$ \\
Sulphite reducing & Sheep & $1.15 \pm 1.07$ & $10^{3}$ \\
Clostridium & Cow & $27 \pm 15.60$ & 50 \\
& Goat & $13 \pm 18.35$ & 50 \\
S. aureus & Sheep & $51 \pm 11.30$ & 50 \\
& Cow & Absence & Absence \\
& Goat & Absence & Absence \\
Salmonella spp. & Sheep & Absence & Absence \\
& Cow & Absence & Absence \\
& Goat & Absence & Absence \\
& Sheep & Absence & Absence \\
\hline
\end{tabular}

TMAF: Total Mesophilic Aerobic Flora; T. Col.: total Coliforms; F. Col.: fecal Coliforms; SEM: Standard Error Mean.
Milk density is between $1.03 \pm 6.33 ; 1.02 \pm 7.44$ and $1.03 \pm 4.08 \mathrm{~kg} / \mathrm{m}^{3}$ for cow's milk, goat's milk, and sheep's milk, respectively. In addition, a significant difference is recorded between the milk of the three species, where the density of goat's milk is the lowest $(p<0.05)$.

Fat content recorded is $3.28 \%$ and $3.23 \%$ for cow's milk and goat milk respectively. These results are very close to those cited in the literature (3.7\% and $4.1 \%$ for cow's milk and goat's milk, respectively) (Boudalia et al., 2016a; El Galiou et al., 2015). However, a very lean fat content was recorded for sheep's milk $(1.82 \%)$. This significant difference $(\mathrm{p}<0.05)$ is not consistent with data from the literature, where sheep's milk is considered as being a fatty milk (Fat content: 7.9\%) (Park, 2006; Park et al., 2007). However, these results are probably due to the feed abundance, Hamidi et al. (2018) found lower fat content in a semiarid region of Algeria where plant abundant and richness is lower.

Results from dry degreased extract (TDE) shown that goat's milk contains less TDE (6.61\%); this result is much below the standard (13.4\%). In the same way, TDE results recorded in cow's milk (8.55\%) and sheep's milk (9.77\%) 
remain relatively low compared to the standards $(12.8 \%$ and $18.3 \%$ for cow's milk and sheep's milk respectively) (Food and Agriculture Organization of the United Nations, 2002; Renhe et al., 2019). The lactose content is $(2.97 \%, 4.70 \%$ and $4.30 \%)$ in goat, cow and sheep respectively $(p<0.05$, Table 1). The results obtained are slightly lower than data from the literature (Renhe et al., 2019).

Total protein (Table 1) indicates that the raw cow's milk is between 2.75 to $4.15 \%$ [27.5-41.5 g/L]. For goat and sheep respectively, the protein level of $3.05 \%$ and $4.63 \%$ was recorded. These rates are in line with the norms for goat's milk. In sheep, protein level remains higher than the protein content in milk from the other two species $(p<0.05)$.

Conductivity rate is $4.94 \pm 0.75 \mathrm{mS} / \mathrm{cm} ; 4.55 \pm 0.55 \mathrm{mS} / \mathrm{cm}$; $3.87 \pm 0.19 \mathrm{mS} / \mathrm{cm}$ for cow, goat and sheep's milk respectively. These values were in good agreement with the data published by Park et al. (2007). The $\mathrm{pH}$ recorded is $6.48 \pm 0.19,6.63 \pm 0.08$, $6.71 \pm 0.24$ for cow, goat and sheep milk, respectively. These values are consistent with the standards (Park, 2006). Also, a significant difference is recorded between the $\mathrm{pH}$ of cow's milk and that of the sheep $(p<0.05)$, where cow's milk appears to be more acidic (Table 1 ).

Minerals and Vitamins (\%) level observed were $0.70 \pm 0.13 \%$; $0.50 \pm 0.14 \% ; 0.73 \pm 0.02 \%$ for cow's, goat's and sheep's milk, respectively. A significant difference was found between the level of minerals and vitamins (\%) in cow's and sheep's milk $v s$. goat's milk where a goat's milk seems to be less rich (Table 1).

The freezing point recorded was $-0.55 \pm 0.11^{\circ} \mathrm{C}$; $-0.38 \pm 0.13{ }^{\circ} \mathrm{C} ;-0.56 \pm 0.03^{\circ} \mathrm{C}$ for cow, goat and sheep milk respectively (Table 1). A significant difference was recorded, where goat's milk has a higher freezing point compared to the other two types of milk (cow and sheep). The values of cow's milk and sheep's milk are consistent with standards; however, the results of goat's milk are relatively lower compared to standards (Food and Agriculture Organization of the United Nations, 2002; Renhe et al., 2019). This difference in physicochemical qualities for goat milk may be due to a wetting of six samples of goat's milk (6/9).

For bacteriological analysis, counting of aerobic mesophilic flora for raw milk samples showed an average microbial load of $1.13 \times 10^{5} ; 0.87 \times 10^{5} ; 1.37 \times 10^{5} \mathrm{CFU} / \mathrm{mL}$ for cow, goat and sheep milk respectively. These values consistent with the results of raw cow milk gathered in Guelma region in the northeastern of Algeria (Boudalia et al., 2016a), and who have been a satisfactory quality of raw milk in light of standard $\left(10^{5} \mathrm{UFC} / \mathrm{mL}\right)$. The sulphite reducing Clostridium was less present with low concentrations in the samples analyzed for the three species. The averages of the enumerated bacteria for cow, goat and sheep's milk are $<50 \mathrm{CFU} / \mathrm{mL}$. Unlike studies of Ghazi \& Niar (2011), Hamiroune et al. (2014) and Bachtarzi et al. (2015) in other regions in Algeria, no Staphylococcus aureus contamination was recorded. These results provide that the hygienic quality of the milk of the three species is very satisfactory and suitable for consumption or processing.

\subsection{Data collection about the traditional preparation of "Bouhezza"}

A survey was conducted among the local people of several provinces in the northeastern of Algeria to understand the traditional process and knowledge of "Bouhezza" preparation. This survey permitted to identify a common procedure for the "Bouhezza" cheese production. This procedure is schematically represented in Figure 2.

"Bouhezza" was traditionally the product of the processing of goat and sheep milk, but the current trend seems to be towards the use of cow milk (Aissaoui Zitoun et al., 2011, 2012; Licitra et al., 2019; Medjoudj et al., 2017a, b).

The cheese is obtained after transformation of the "Lben" in a "Chekoua" made of goatskin previously treated with salt and juniper (Aissaoui Zitoun et al., 2011). Draining, salting and refining "Bouhezza" are performed simultaneously in the "Chekoua". During the ripening period, "Lben" and milk are added to the contents of the "Chekoua".

In our study, nine manufacturing experiments were carried out via the traditional diagram and for ten weeks. During each experiment, "Chekoua" received each three-day an amount of $1.5 \mathrm{~L}$ of salted "lben" ( $25 \mathrm{~g}$ of salt per L). At the end of the manufacturing (for about 1 to 1.5 last weeks) and to adjust organoleptic characteristics of the "Bouhezza" cheese (salt and acidity), additions of whole raw milk were done. In this study, the additions of fresh whole milk were perused until the tenth week to observe eventual evolutions in this case. During manufacturing, the "Chekoua" was suspended in an aerated room and daily washed and scraped on the external face (Figure 3).

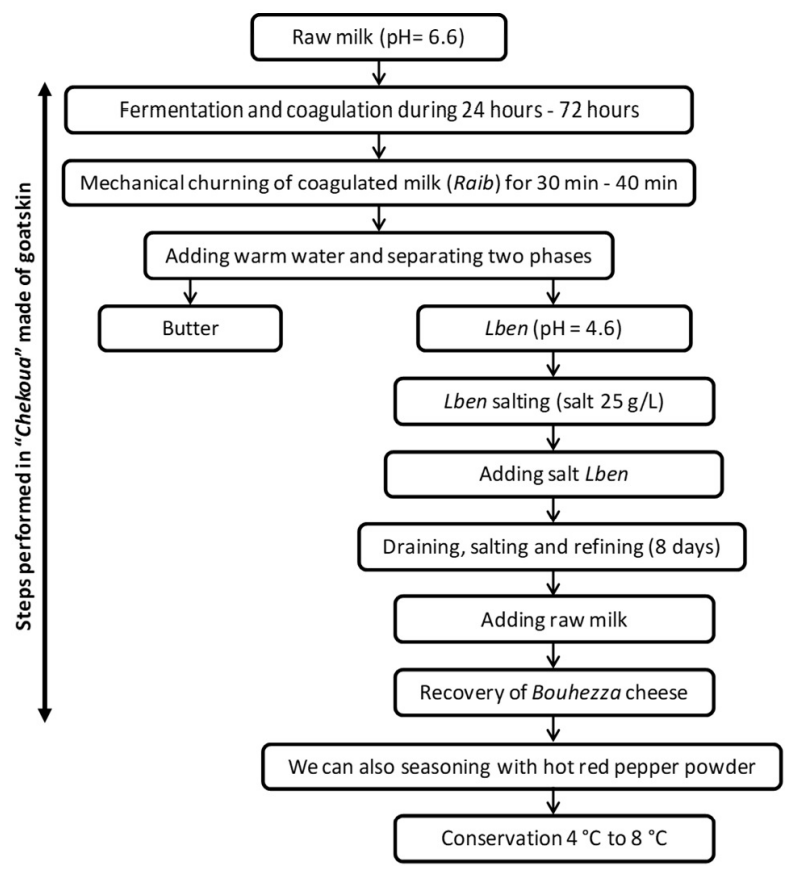

Figure 2. Illustrative global traditional diagram of the manufacturing processes of "Bouhezza" cheese-making. "Bouhezza" is obtained after transformation of the "Lben" in "Chekoua" made of goatskin previously treated with salt and juniper. Draining, salting and refining of cheese are performed simultaneously in the "Chekoua". 

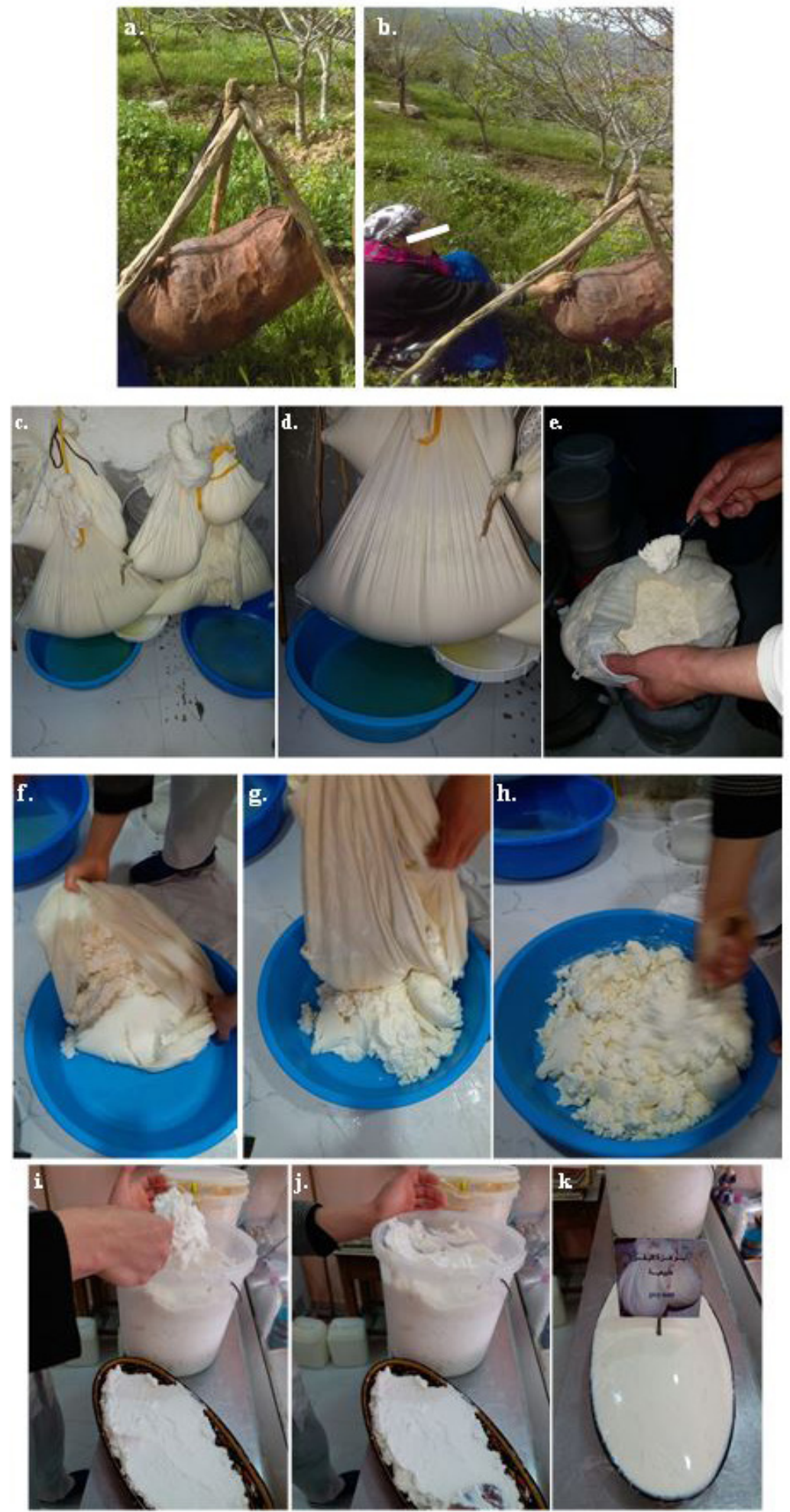

Figure 3. "Bouhezza" processing steps: After spontaneous coagulation of raw milk at room temperature which it takes 24 to 72 hours depending on the seasonal temperature, the curdled milk called "Rayeb" (or "Raïb" was obtained. A farmer woman use "Chekoua" or "skinbag" made of goatskin previously treated with salt and juniper to transform the "Raïb" (a quantity of 3.6 to $3.8 \mathrm{~L}$ ) into "Lben" by churning for 30 to 40 minutes. During this step, the addition of lukewarm water to the "Raïb" (about $10 \%(\mathrm{v} / \mathrm{v})$ ) makes it possible to reduce the temperature to the proper level to collect the grains of butter. Extraction of traditional butter (Zebda Beldia) and salt adding (1 tablespoon/L) is realized at this stage (a) and (b). (c), (d) and (e) cheese draining; this step is carried out in "Chekoua". However, it can also be done in cloth bags to facilitate sewage. Raw milk $(100 \mathrm{~mL} / 4 \mathrm{~L})$ can be added to adjust the acidity and salinity of the finished product. (f), (g) and (h) recovery of "Bouhezza" cheese is carried out after the draining step. (i), (j) and (k) "Bouhezza" Cheese is stored in pottery jars/ glass or food containers for a few weeks at a temperature that varies between $4{ }^{\circ} \mathrm{C}$ and $8{ }^{\circ} \mathrm{C}$. People generally take it after lunch and dinner. 


\subsection{Cheese yields analysis}

Figure 4 show the quantities of dairy products (whey, butter and cheese) following the transformation of milk from three species into "Bouhezza" cheese. Although the initial volume of milk used in cheese making is almost the same (no significant difference), a significant difference was recorded after processing in terms of $i$ ) volume of whey harvested after draining. This volume is greater than three liters for all the milks except for sheep's milk, which gave the lowest volume $(p<0.05)$; ii) butter quantity manufactured after churning which is around $0.24 \mathrm{~kg}$ for sheep's milk and $0.15 \mathrm{~kg}$ for cow's and goat's milk $(p<0.05)$; iii) "Bouhezza" quantity and cheese yield, indeed sheep's milk seems to be the most efficient in terms of cheese yield $(p<0.05)$ (Figure 4).

"Bouhezza" yield is an economically relevant variable which is influenced by different factors such as milk quality and cheese-making methods (Lucey \& Kelly, 1994). Our results showed that there was an interspecific difference in cheese yield between cows, goats and sheep. While some studies show that cheese yield is higher in cows than goat (Rasheed et al., 2016), our study and others show the opposite (Hamidi et al., 2018; Mallatou \& Pappa, 2005). Different factors might produce this interspecific difference, including those related to the milk composition and quality such as genetic variants of casein, fat and protein (Banks et al., 1981; Fenelon \& Guinee, 1999; Verdier-Metz et al., 2001), seasonal variations (Sánchez-Gamboa et al., 2018), microbial counts and diversity (Vladimír et al., 2020) and cheese-processing methodology (Lawrence, 1993). In our study, "Bouhezza"-processing methodology and season are the same, however, we found higher fat and protein content in goat compared to cow milk, which probably contributed to the increase in cheese yield (Lucey \& Kelly, 1994). In sheep milk, we found higher larger casein micelle size, which affect their renneting properties and coagulation time. Also, the higher casein content n, which functions as a chelator of divalent (or higher valence) ions, is associated with higher content of those mineral contents than in cow, and goat milk. The average fat globule size is smallest $(<3.5 \mu \mathrm{m})$ in sheep milk followed by goat and cow milk. Therefore, cheese yield per volume of milk is the highest among ruminant milk (Silanikove et al., 2016).

\subsection{Sensory analysis of "Bouhezza" cheese}

The sensory evaluation scores are shown in Table 3 and Figure 5. From our panelist $50 \%$ are women, they are between 18 and 30 years old, and $95 \%$ of them consume cheese at least once a week. "Bouhezza" cheese from cow milk had a hedonic score greater than or equal to 5 for the 5 descriptors (overall appreciation, taste, texture, smell and color).

Panelists determined that "Bouhezza" cheese is accepted except "Bouhezza" from goat's milk, in which the hedonic note is less than 5. Furthermore, the sensory acceptance of the product tested in this study is very similar to that found by Dal Bello et al. (2017) for fresh cheese from raw cow milk. Also, from literature, goat and sheep cheese are not preferred by large proportion of people which are not appreciate a strong goaty or sheepy aroma, even though they are not very familiar with these aromas (Ryffel et al., 2008). In the same way, Costa et al. (2015) have evaluated the acceptance of fermented cow's and goat's milks. Results have shown that fermented cow's milk was well accepted compared to fermented goat's milk.

Table 3. Hedonic scoring test for "Bouhezza” cheese (with 5 descriptors).

\begin{tabular}{ccccccc}
\hline Descriptors & & Global appreciation & Taste & Texture & Odor & Color \\
\hline \multirow{3}{*}{ Hedonic note } & Cow & $5.90 \pm 0.81$ & $5.25 \pm 0.87$ & $6.25 \pm 0.82$ & $7.75 \pm 0.78$ & $6.45 \pm 0.86$ \\
& Goat & $4.75 \pm 0.90$ & $4.00 \pm 0.76$ & $4.60 \pm 0.71$ & $7.60 \pm 0.72$ & $5.10 \pm 0.92$ \\
& Sheep & $5.50 \pm 0.65$ & $4.65 \pm 0.76$ & $4.55 \pm 0.72$ & $7.70 \pm 0.64$ & $5.10 \pm 0.64$ \\
\hline
\end{tabular}
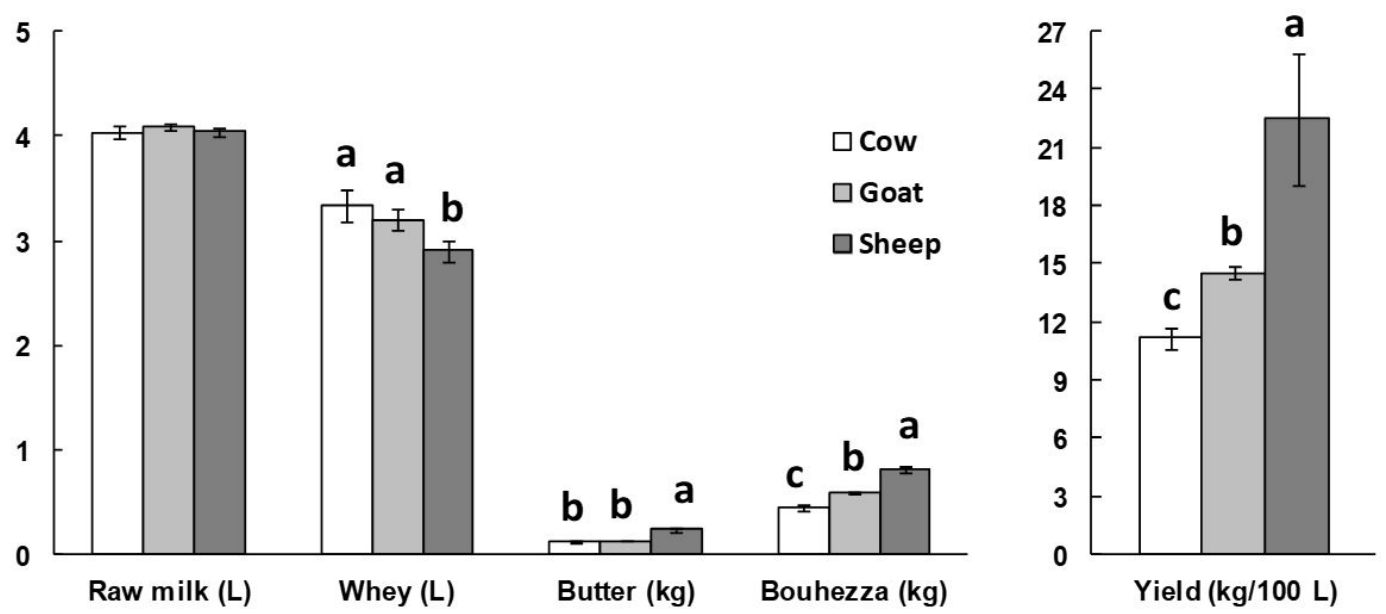

Figure 4. "Bouhezza" cheese yield analysis from cow's, goat's and sheep's milk collected in the regions of Guelma, Souk Ahras, Tebessa and Djelfa $(n=9 /$ species $)$. Results are expressed on average \pm SEM. The letters on the diagrams show significant differences between each milk for the same parameter $(p<0.05)$ (One-way ANOVA, Tukey in post-hoc). 


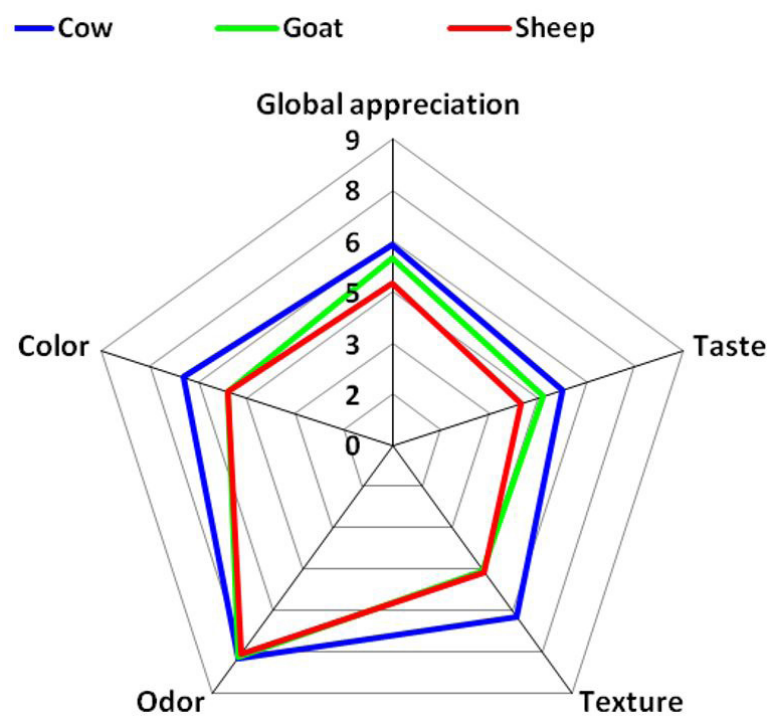

Figure 5. Mean scores of sensory acceptability test (with 5 descriptors) of different artisanal "Bouhezza" cheese produced from cow's, goat's and sheep's milk collected in the regions of Guelma, Souk Ahras, Tebessa and Djelfa.

\section{Conclusions}

In summary, "Bouhezza" cheese occupies a very important socio-economic place established in the rural and peri-urban environment. It is a fermented soft-ripened cheese produced empirically in several regions of Algeria. Originally, "Bouhezza" was traditionally the product of the processing of goat milk and sheep, but the current trend seems to be towards the use of cow milk (Aissaoui Zitoun et al., 2011, 2012; Licitra et al., 2019; Medjoudj et al., 2017a, b). In this study, we have elaborated the traditional fabrication diagram of this cheese from a field survey, and then we have produced the "Bouhezza" cheese from cow's milk, goat's milk and sheep's milk. Before cheese making, the raw milk from the tree species (cow, goat and sheep) was analyzed (physical, chemical, and microbiological properties). The cheese is obtained after transformation of the "Lben" in a "Chekoua" made of goatskin. Draining, salting and refining "Bouhezza" are performed simultaneously in the "Chekoua". During the ripening period, "Lben" and milk are added to the contents of the "Chekoua".

Results from the physicochemical and bacteriological analysis of milk show that all criteria analyzed respond almost to the required standard. The sensory qualities of the three types of cheese show that cow cheese was classified as the most satisfactory cheese for the majority of criteria (taste. color and texture). Based on a rate of return equivalent to that obtained in our milk production trials, the cheese processing seems very viable and cost-effective for the breeder better than their marketing as raw milk.

\section{Acknowledgements}

This work is part of the research activity carried out within: i) the "Dairy production: Optimization of production techniques, valorization and quality control" project funded by the Algerian
Ministry of Higher Education and Scientific Research, grant agreement no: D00L01UN240120180001; ii) ARIMNet2-BOVISOL (Coordination of Agricultural Research in the Mediterranean. EC FP7 project no 618127; www.arimnet2.net)-BOVISOL (Breeding and management practices of indigenous bovine breeds: Solutions towards a sustainable future) project funded by the Algerian Ministry of Higher Education and Scientific Research and Scientific Research and from the Directorate General for Scientific Research and Technological Development (DGRSDT).

We thank the breeders from different provinces and different farms who provided the milk necessary for the realization of this study. We would like to thank all of the respondents for giving the valuable information from the survey study for the artisanal cheese making, and we are very grateful to the entire volunteer panelist for their participation in the sensory study.

\section{References}

Aissaoui Zitoun, O., Benatallah, L., Ghennam, E.-H., \& Zidoune, M. N. (2011). Manufacture and characteristics of the traditional Algerian ripened Bouhezza cheese. Journal of Food Agriculture and Environment, 9, 96-100.

Aissaoui Zitoun, O., Pediliggieri, C., Benatallah, L., Lortal, S., Licitra, G., Zidoune, M. N., \& Carpino, S. (2012). Bouhezza, a traditional algerian raw milk cheese, made and ripened in goatskin bags. Journal of Food Agriculture and Environment, 10(2), 289-295.

Bachtarzi, N., Amourache, L., \& Dehkal, G. (2015). Quality of raw milk for the manufacture of a Camembert -type soft cheese in a dairy of Constantine (eastern Algeria). International Journal of Innovation and Scientific Research, 17(1), 34-42.

Banks, J. M., Muir, D., Banks, W., \& Wilson, A. (1981). Cheese yield: composition does matter. Dairy Industries International, 46, 15.

Ben Danou, C. (1929). Quelques notes de laiterie sur l'Algérie. Le Lait, 9(82), 161-163.

Benamara, R. N., Gemelas, L., Ibri, K., Moussa-Boudjemaa, B., \& Demarigny, Y. (2016). Sensory, microbiological and physico-chemical characterization of Klila, a traditional cheese made in the southwest of Algeria. African Journal of Microbiological Research, 10(41), 1728-1738. http://dx.doi.org/10.5897/AJMR2016.8264.

Benkerroum, N. (2013). Traditional fermented foods of north african countries: technology and food safety challenges with regard to microbiological risks. Comprehensive Reviews in Food Science and Food Safety, 12(1), 54-89. http://dx.doi.org/10.1111/j.15414337.2012.00215.x.

Bertozzi, L., \& Panari, G. (1993). Cheeses with appellation d'origine contrôlée (AOC): factors that affect quality. International Dairy Journal, 3(4), 297-312. http://dx.doi.org/10.1016/0958-6946(93)90019-V.

Boudalia, S., Benati, D., Boukharoub, R., Chemakh, B., \& Chemmam, M. (2016a). Physico-chemical properties and hygienic quality of raw and reconstituted milk in the region of Guelma-Algeria. International Journal of Agricultural Research, 11(2), 77-83. http:// dx.doi.org/10.3923/ijar.2016.77.83.

Boudalia, S., Mezroua, E. Y., Bousbia, A., Khaldi, M., Merabti, W., \& Namoune, H. (2016b). Evaluation of the Stability of the Physico-chemical Properties and Sensory Qualities of Farfalle Pasta from the Region of Guelma, Algeria. Malaysian Journal of Nutrition, 22(3), 443-453.

Chaker, S. (Ed.). (1986). Alger - Amzwar. In G. Camps (Ed.), Encyclopédie berbère (Vol. 4). Paris: Centre de Recherche Berbère. Retrieved from http://journals.openedition.org/encyclopedieberbere/2465 
Conti-Silva, A. C., Silva, M. E., \& Arêas, J. A. (2011). Sensory acceptability of raw and extruded bovine rumen protein in processed meat products. Meat Science, 88(4), 652-656. http://dx.doi.org/10.1016/j. meatsci.2011.02.024. PMid:21414726.

Costa, M. P., Balthazar, C. F., Rodrigues, B. L., Lazaro, C. A., Silva, A. C. O., Cruz, A. G., \& Conte Junior, C. A. (2015). Determination of biogenic amines by high-performance liquid chromatography (HPLC-DAD) in probiotic cow's and goat's fermented milks and acceptance. Food Science \& Nutrition, 3(3), 172-178. http://dx.doi. org/10.1002/fsn3.200. PMid:25987991.

Dal Bello, B., Torri, L., Piochi, M., Bertolino, M., \& Zeppa, G. (2017). Fresh cheese as a vehicle for polyunsaturated fatty acids integration: effect on physico-chemical, microbiological and sensory characteristics. International Journal of Food Sciences and Nutrition, 68(7), 800-810. http://dx.doi.org/10.1080/09637486.2017.1301891. PMid:28320208.

Dubeuf, J.-P., Ruiz Morales, F. A., \& Castel Genis, J. M. (2010). Initiatives and projects to promote the Mediterranean local cheeses and their relations to the development of livestock systems and activities. Small Ruminant Research, 93(2), 67-75. http://dx.doi.org/10.1016/j. smallrumres.2010.03.001.

El Galiou, O., Zantar, S., Bakkali, M., Laglaoui, A., Centeno, J. A., \& Carballo, J. (2015). Chemical and microbiological characteristics of traditional homemade fresh goat cheeses from Northern Morocco. Small Ruminant Research, 129, 108-113. http://dx.doi.org/10.1016/j. smallrumres.2015.06.005.

Fenelon, M., \& Guinee, T. (1999). The effect of milk fat on Cheddar cheese yield and its prediction, using modifications of the Van Slyke cheese yield formula. Journal of Dairy Science, 82(11), 2287-2299. http://dx.doi.org/10.3168/jds.S0022-0302(99)75477-9.

Food and Agriculture Organization of the United Nations - FAO. (2002). Codex committee on milk and milk products, preliminary draft revision of the standard on whey powder. Rome.

Franco, I., Prieto, B., Bernardo, A., González Prieto, J., \& Carballo, J. (2003). Biochemical changes throughout the ripening of a traditional Spanish goat cheese variety (Babia-Laciana). International Dairy Journal, 13(2), 221-230. http://dx.doi.org/10.1016/S0958-6946(02)00154-1.

Ghazi, K., \& Niar, A. (2011). Qualité hygiénique du lait cru de vache dans les différents élevages de la Wilaya de Tiaret (Algérie). Tropicultura, 29(4), 193-196.

Ghosh, K., Maity, C., Adak, A., Halder, S. K., Jana, A., Das, A., Parua, S., Das Mohapatra, P. K., Pati, B. R., \& Mondal, K. C. (2014). Ethnic preparation of haria, a rice-based fermented beverage, in the Province of Lateritic West Bengal, India. Ethnobotany Research and Applications, 12, 39-49.

Hamidi, M., Hachi, M., Lahrech, A., \& Choukri, A. (2018). Production fromagère par un extrait de kaolin du gésier de poulet avec du lait de vache, de brebis ou de chèvre dans la steppe Algérienne. Livestock Research for Rural Development, 30(11). Retrieved from http://www. lrrd.org/lrrd30/11/med.h30192.html

Hamiroune, M., Berber, A., \& Boubekeur, S. (2014). Bacteriological quality of raw milk from local and improved cows in the region of Jijel and Blida (Algeria) and impact on public health. Annales de Medecine Veterinaire, 158, 137-144.

Hatzikamari, M., Litopoulou-Tzanetaki, E., \& Tzanetakis, N. (1999). Microbiological characteristics of Anevato: a traditional Greek cheese. Journal of Applied Microbiology, 87(4), 595-601. http://dx.doi. org/10.1046/j.1365-2672.1999.00857.x. PMid:10583688.

International Dairy Federation - IDF. (1991). Milk and milk products enumeration of microorganisms, colony count at $30^{\circ} \mathrm{C}$. Brussels: IDF.
Kamimura, B. A., Magnani, M., Luciano, W. A., Campagnollo, F. B., Pimentel, T. C., Alvarenga, V. O., Pelegrino, B. O., Cruz, A. G., \& Sant'Ana, A. S. (2019). Brazilian artisanal cheeses: an overview of their characteristics, main types and regulatory aspects. Comprehensive Reviews in Food Science and Food Safety, 18(5), 1636-1657. http:// dx.doi.org/10.1111/1541-4337.12486.

Khoualdi, G. (2017). Caractérisation du fromage traditionnel algérien «Medeghissa» (Magister). Université de Constantine 1, Institut de la Nutrition, de l'Alimentation et des Technologies Agro-Alimentaires, Algérie. Retrieved from https://bu.umc.edu.dz/theses/agronomie/ KHO7145.pdf

Lawrence, R. (1993). Processing conditions: factors affecting the yield of cheese. Brussels: International Dairy Federation.

Leclercq-Perlat, M.-N., Saint-Eve, A., Le Jan, E., Raynaud, S., Morge, S., Lefrileux, Y., \& Picque, D. (2019). Physicochemical and sensory evolutions of the lactic goat cheese Picodon in relation to temperature and relative humidity used throughout ripening. Journal of Dairy Science, 102(6), 5713-5725. http://dx.doi.org/10.3168/jds.201815958. PMid:31005324.

Leksir, C., \& Chemmam, M. (2015). Contribution on the characterization of Klila, a traditional cheese in east of Algeria. Livestock Research for Rural Development, 27(5).

Leksir, C., Boudalia, S., Moujahed, N., \& Chemmam, M. (2019). Traditional dairy products in Algeria: case of Klila cheese. Journal of Ethnic Foods, 6(1), 7. http://dx.doi.org/10.1186/s42779-019-0008-4.

Licitra, G., Caccamo, M., \& Lortal, S. (2019). Artisanal products made with raw milk. In L. A. Nero \& A. F. Carvalho (Eds.), Raw milk (Chap. 9, pp. 175-221). San Diego: Academic Press. http://dx.doi. org/10.1016/B978-0-12-810530-6.00009-2.

Lucey, J., \& Kelly, J. (1994). Cheese yield. International Journal of Dairy Technology, 47(1), 1-14. http://dx.doi.org/10.1111/j.1471-0307.1994. tb01264.x.

Mallatou, H., \& Pappa, E. (2005). Comparison of the characteristics of teleme cheese made from ewe's, goat's and cow's milk or a mixture of ewe's and goat's milk. International Journal of Dairy Technology, 58(3), 158-163. http://dx.doi.org/10.1111/j.1471-0307.2005.00204.x.

Marino, V. M., Belbeldi, A., La Terra, S., Manenti, M., Licitra, G., \& Carpino, S. (2012). Survey of fat soluble antioxidants, linolenic acid and conjugated linoleic acid content of traditional Algerian Bouhezza cheese. Journal of Food Agriculture and Environment, 10(3-4), 186-190.

McSweeney, P. L. H., Ottogalli, G., \& Fox, P. F. (2017). Diversity and classification of cheese varieties: an overview. In P. L. H. McSweeney, P. F. Fox, P. D. Cotter \& D. W. Everett (Eds.), Cheese (Chap. 31, 4th ed., pp. 781-808). San Diego: Academic Press. http://dx.doi. org/10.1016/B978-0-12-417012-4.00031-4.

Medjoudj, H., Aouar, L., Zidoune, M. N., \& Hayaloglu, A. A. (2017a). Proteolysis, microbiology, volatiles and sensory evaluation of Algerian traditional cheese Bouhezza made using goat's raw milk. International Journal of Food Properties, 20(Suppl. 3), S3246-S3265. http://dx.doi.org/10.1080/10942912.2017.1375515.

Medjoudj, H., Zidoune, M. N., \& Hayaloglu, A. A. (2017b). Proteolysis and volatile profile in the Algerian traditional Bouhezza cheese made using raw goat's milk. International Journal of Food Properties, 20(8), 1876-1893. http://dx.doi.org/10.1080/10942912.2016.1222588.

Moraes, G. M. D., Santos, K. M. O., de Barcelos, S. C., Lopes, S. A., \& do Egito, A. S. (2018). Potentially probiotic goat cheese produced with autochthonous adjunct culture of Lactobacillus mucosae: microbiological, physicochemical and sensory attributes. $L W T$ Food Science and Technology, 94, 57-63. http://dx.doi.org/10.1016/j. lwt.2018.04.028. 
Oliszewski, R., Cisint, J. C., \& Núñez de Kairúz, M. (2007). Manufacturing characteristics and shelf life of Quesillo, an Argentinean traditional cheese. Food Control, 18(6), 736-741. http://dx.doi.org/10.1016/j. foodcont.2006.03.010.

Oliveira, E. W., Esmerino, E. A., Carr, B. T., Pinto, L. P. F., Silva, H. L. A., Pimentel, T. C., Bolini, H. M. A., Cruz, A. G., \& Freitas, M. Q. (2017). Reformulating Minas Frescal cheese using consumers' perceptions: insights from intensity scales and check-all-that-apply questionnaires. Journal of Dairy Science, 100(8), 6111-6124. http:// dx.doi.org/10.3168/jds.2016-12335. PMid:28551189.

Park, Y. W. (2006). Goat milk-chemistry and nutrition. In Y. W. Park (Ed.), Handbook of milk of non-bovine mammals. Oxford: John Wiley \& Sons.

Park, Y. W., Juárez, M., Ramos, M., \& Haenlein, G. F. W. (2007). Physico-chemical characteristics of goat and sheep milk. Small Ruminant Research, 68(1), 88-113. http://dx.doi.org/10.1016/j. smallrumres.2006.09.013.

Quetier, F., Marty, P., \& Lepart, J. (2005). Farmers' management strategies and land use in an agropastoral landscape: roquefort cheese production rules as a driver of change. Agricultural Systems, 84(2), 171-193. http://dx.doi.org/10.1016/j.agsy.2004.05.005.

Ramalho Ribeiro, J. M. C., Horta, A. E. M., Mosconi, C., \& Rosati, A. (2006). Animal products from the Mediterranean area (Vol. 119). Wageningen: Wageningen Academic Publishers.

Rasheed, S., Qazi, I. M., Ahmed, I., Durrani, Y., \& Azmat, Z. (2016). Comparative study of cottage cheese prepared from various sources of milk. Proceedings of the Pakistan Academy of Sciences: Pakistan Academy of Sciences B, Life and Environmental Sciences, 53(4), 269-282.

Renhe, I. R. T., Perrone, Í. T., Tavares, G. M., Schuck, P., \& Carvalho, A. F. (2019). Physicochemical characteristics of raw milk. In L. A. Nero \& A. F. De Carvalho (Eds.), Raw milk (Chap. 2, pp. 29-43). San Diego: Academic Press. http://dx.doi.org/10.1016/B978-0-12810530-6.00002-X.

Ruvalcaba-Gómez, J. M., Ruiz-Espinosa, H., Arteaga-Garibay, R. I., Rojas-López, M., Amador-Espejo, G. G., Anaya-Esparza, L. M., \& Delgado-Macuil, R. J. (2020). Texture, physicochemical and sensory properties of artisanal Adobera cheese from Los Altos de Jalisco, a genuine Mexican cheese. International Journal of Dairy Technology, 73(2), 411-420. http://dx.doi.org/10.1111/1471-0307.12676.

Ryffel, S., Piccinali, P., \& Bütikofer, U. (2008). Sensory descriptive analysis and consumer acceptability of selected Swiss goat and sheep cheeses. Small Ruminant Research, 79(1), 80-86. http://dx.doi.org/10.1016/j. smallrumres.2008.07.006.
Sánchez-Gamboa, C., Hicks-Pérez, L., Gutiérrez-Méndez, N., Heredia, N., García, S., \& Nevárez-Moorillón, G. V. (2018). Seasonal influence on the microbial profile of Chihuahua cheese manufactured from raw milk. International Journal of Dairy Technology, 71(S1), 81-89. http://dx.doi.org/10.1111/1471-0307.12423.

Sant'Anna, F. M., Acurcio, L. B., Alvim, L. B., Castro, R. D., Oliveira, L. G., Silva, A. M., Nunes, Á. C., Nicoli, J. R., \& Souza, M. R (2017). Assessment of the probiotic potential of lactic acid bacteria isolated from Minas artisanal cheese produced in the Campo das Vertentes region, Brazil. International Journal of Dairy Technology, 70(4), 592601. http://dx.doi.org/10.1111/1471-0307.12422.

Sęczyk, Ł., Świeca, M., \& Gawlik-Dziki, U. (2016). Effect of carob (Ceratonia siliqua L.) flour on the antioxidant potential, nutritional quality, and sensory characteristics of fortified durum wheat pasta. Food Chemistry, 194, 637-642. http://dx.doi.org/10.1016/j. foodchem.2015.08.086. PMid:26471602.

Silanikove, N., Leitner, G., \& Merin, U. (2016). Influence of animal health, breed, and diet on non-cow milk composition. In E. Tsakalidou \& K. Papadimitriou (Eds.), Non-bovine milk and milk products (Chap. 4, pp. 61-79). San Diego: Academic Press. http://dx.doi.org/10.1016/ B978-0-12-803361-6.00004-1.

Tadjine, D., Boudalia, S., Bousbia, A., Khelifa, R., Mebirouk Boudechiche, L., Tadjine, A., \& Chemmam, M. (2019). Pasteurization effects on yield and physicochemical parameters of cheese in cow and goat milk. Food Science and Technology. In press. http://dx.doi. org/10.1590/fst.13119.

Terzic-Vidojevic, A., Tolinacki, M., Nikolic, M., Veljovic, K., Jovanovic, S., Macej, O., \& Topisirovic, L. (2013). Artisanal Vlasina raw goat's milk cheese: evaluation and selection of autochthonous lactic acid bacteria as starter cultures. Food Technology and Biotechnology, 51(4), 554-563.

Verdier-Metz, I., Coulon, J.-B., \& Pradel, P. (2001). Relationship between milk fat and protein contents and cheese yield. Animal Research, 50(5), 365-371. http://dx.doi.org/10.1051/animres:2001138.

Vladimír, D., Miloslava, K., Markéta, M., Jaroslava, H., \& Petr, R. (2020). Microbial diversity of Livanjski cheese with the emphasis on lactic acid bacteria based on culture-dependent and sequencing method. International Journal of Dairy Technology, 73(1), 202-214. http:// dx.doi.org/10.1111/1471-0307.12638.

Volpini-Rapina, L. F., Sokei, F. R., \& Conti-Silva, A. C. (2012). Sensory profile and preference mapping of orange cakes with addition of prebiotics inulin and oligofructose. Lebensmittel-Wissenschaft + Technologie, 48(1), 37-42. http://dx.doi.org/10.1016/j.lwt.2012.03.008. 